\title{
Chimeric Antigen Receptor Expressing Natural Killer Cells for the Immunotherapy of Cancer
}

\author{
Rohtesh S. Mehta* and Katayoun Rezvani* \\ MD Anderson Cancer Center, Houston, TX, United States
}

Adoptive cell therapy has emerged as a powerful treatment for advanced cancers resistant to conventional agents. Most notable are the remarkable responses seen in patients receiving autologous CD19-redirected chimeric antigen receptor (CAR) T cells for the treatment of $\mathrm{B}$ lymphoid malignancies; however, the generation of autologous products

\section{OPEN ACCESS}

Edited by:

Ignacio Melero,

Centro de Investigación Médica Aplicada (CIMA), Spain

Reviewed by:

Daniel Olive,

Institut National de la Santé et de la

Recherche Médicale (INSERM),

France

Manel Juan,

Hospital Clínic, Spain

Michael R. Verneris,

University of Colorado Denver,

United States

*Correspondence:

Rohtesh S. Mehta

rmehta1@mdanderson.org;

Katayoun Rezvani

krezvani@mdanderson.org

Specialty section:

This article was submitted to Cancer Immunity and Immunotherapy,

a section of the journal

Frontiers in Immunology

Received: 15 November 2017 Accepted: 31 January 2018

Published: 15 February 2018

Citation:

Mehta RS and Rezvani K (2018)

Chimeric Antigen Receptor

Expressing Natural Killer Cells for the

Immunotherapy of Cancer.

Front. Immunol. 9:283.

doi: 10.3389/fimmu.2018.00283 for each patient is logistically cumbersome and has restricted widespread clinical use. A banked allogeneic product has the potential to overcome these limitations, yet allogeneic T-cells (even if human leukocyte antigen-matched) carry a major risk of graft-versus-host disease (GVHD). Natural killer (NK) cells are bone marrow-derived innate lymphocytes that can eliminate tumors directly, with their activity governed by the integration of signals from activating and inhibitory receptors and from cytokines including $\mathrm{IL}-15, \mathrm{IL}-12$, and IL-18. NK cells do not cause GVHD or other alloimmune or autoimmune toxicities and thus, can provide a potential source of allogeneic "off-the-shelf" cellular therapy, mediating major anti-tumor effects without inducing potentially lethal alloreactivity such as GVHD. Given the multiple unique advantages of NK cells, researchers are now exploring the use of CAR-engineered NK cells for the treatment of various hematological and non-hematological malignancies. Herein, we review preclinical data on the development of CAR-NK cells, advantages, disadvantages, and current obstacles to their clinical use.

Keywords: natural killer cells, chimeric antigen receptor, chimeric antigen receptor, chimeric antigen receptor $\mathbf{T}$, chimeric antigen receptor natural killer, cancer, hematopoietic stem cell transplant

\section{INTRODUCTION}

Chimeric antigen receptor (CAR) T cells have gained enormous clinical recognition with remarkable responses reported in patients receiving autologous CD19 (a B cell-specific antigen)-redirected $\mathrm{T}$ cells for the treatment of patients with relapsed or refractory B-cell malignancies (1-9). CAR $\mathrm{T}$ cells are genetically engineered to express a single chain variable fragment $(\mathrm{scFv})$ derived from an antibody on their surface, which is coupled to a T-cell signaling domain, thus rendering them highly antigen-specific in a non-human leukocyte antigen (HLA)-restricted manner $(2,10,11)$. Thus far, the clinical application of CAR T cells has been largely restricted to CD19-expressing B cell malignancies (1-9); however, ongoing studies are testing its applications in other hematological malignancies such as Hodgkin and non-Hodgkin lymphoma, multiple myeloma, and acute myeloid leukemia (12-14). The US Food and Drug Administration recently approved two autologous CD19 CAR T cell products for the treatment of acute lymphoblastic leukemia and certain types of relapsed or refractory large B-cell lymphoma. However, CAR T-cells have several limitations: (i) it is logistically cumbersome to generate an autologous product from patients; (ii) it takes several weeks before 
CAR T cells are generated-making it impractical for patients with aggressive disease; and (iii) generation of clinically relevant doses of CAR T-cells can be unfeasible from heavily pretreated lymphopenic patients. An alternative approach is to use previously collected T cells from an allogeneic source; however, even if HLA-matched, T cells pose a risk of serious graft-versus-host disease (GVHD) (15). In contrast to the popularity of CAR $\mathrm{T}$ cells, the generation and clinical application of CAR natural killer (NK) cells has lagged behind for various reasons, despite the multiple advantages of NK cells. Herein, we describe these barriers and discuss strategies to overcome them.

\section{Advantages of NK Cells for CAR Therapy}

Among cytolytic lymphocytes, NK cells represent on a per cell basis the most efficient effectors against tumors with a distinct mechanism of action (Figure 1) and provide an attractive source of cells for cancer immunotherapy $(16,17)$. In contrast to other lymphocytes such as T or B cells, NK cells do not express rearranged, antigen-specific receptors. Instead, NK cells express germline-encoded receptors, which are either activating or inhibitory. Upon interaction with their ligands on target cells, the receptors induce a positive or a negative signal, respectively (18). The balance of these signals ultimately govern NK effector function $(16,19)$ Among the most heavily studied NK cells receptors are the killer-cell immunoglobulin-like receptors (KIRs) are that recognize classical HLA class-I molecules (HLA- A, -B, and -C). Other receptors belong to the C-type lectin family (CD94 and NKG2s, such as NKG2A, $-\mathrm{B},-\mathrm{C},-\mathrm{D},-\mathrm{E}$, and $-\mathrm{F}$ ) that recognize non-classical HLA class-I molecules (HLA-E and stress-induced MHC-I-related chains-MICA and MICB) [reviewed in Ref.
(20-23)]. Healthy cells are protected from NK mediated lysis by the recognition of "self" HLA molecules on their surface by inhibitory NK receptors protects (24-27). On the other hand, tumor or viral infected cells often downregulate or lose their HLA molecules as an escape mechanism against T-cells $(28,29)$. Loss of HLA class I expression makes them susceptible to lysis by the NK cells due to loss of the inhibitory signal (21, 30-45). Indeed, the clinical significance of NK cell alloreactivity has been demonstrated in multiple studies in the setting of hematopoietic stem cell transplant (HSCT), where patients that received a graft containing alloreactive NK cells had a significantly lower risk of relapse and improved survival (46-55). Adoptive transfer of alloreactive NK cells as a stand-alone therapy (independent of HSCT) also demonstrated encouraging outcomes in a variety of malignancies (56-62). In contrast, several studies of autologous NK cell adoptive therapy showed rather disappointing results (63-71).

Thus, NK cells offer an attractive alternative to T-cells for CAR engineering for a number of reasons: (i) allogeneic NK cells should not cause GVHD, as predicted by observations in murine models $(72,73)$, as well as clinical studies of haploidentical and cord blood (CB)-derived NK cell infusions in patients with hematologic or solid malignancies $(56,59)$; (ii) mature NK cells have a relatively limited life-span, permitting effective antitumor activity while reducing the probability of long-term adverse events, such as prolonged cytopenias due to on-target/off-tumor toxicity to normal tissues such as B cell aplasia (in the case of CD19 CARs), which can last up to 3 years (74); and (iii) CAR-NK cells retain their intrinsic capacity to recognize and target tumor cells through their native receptors; therefore when compared with the CAR

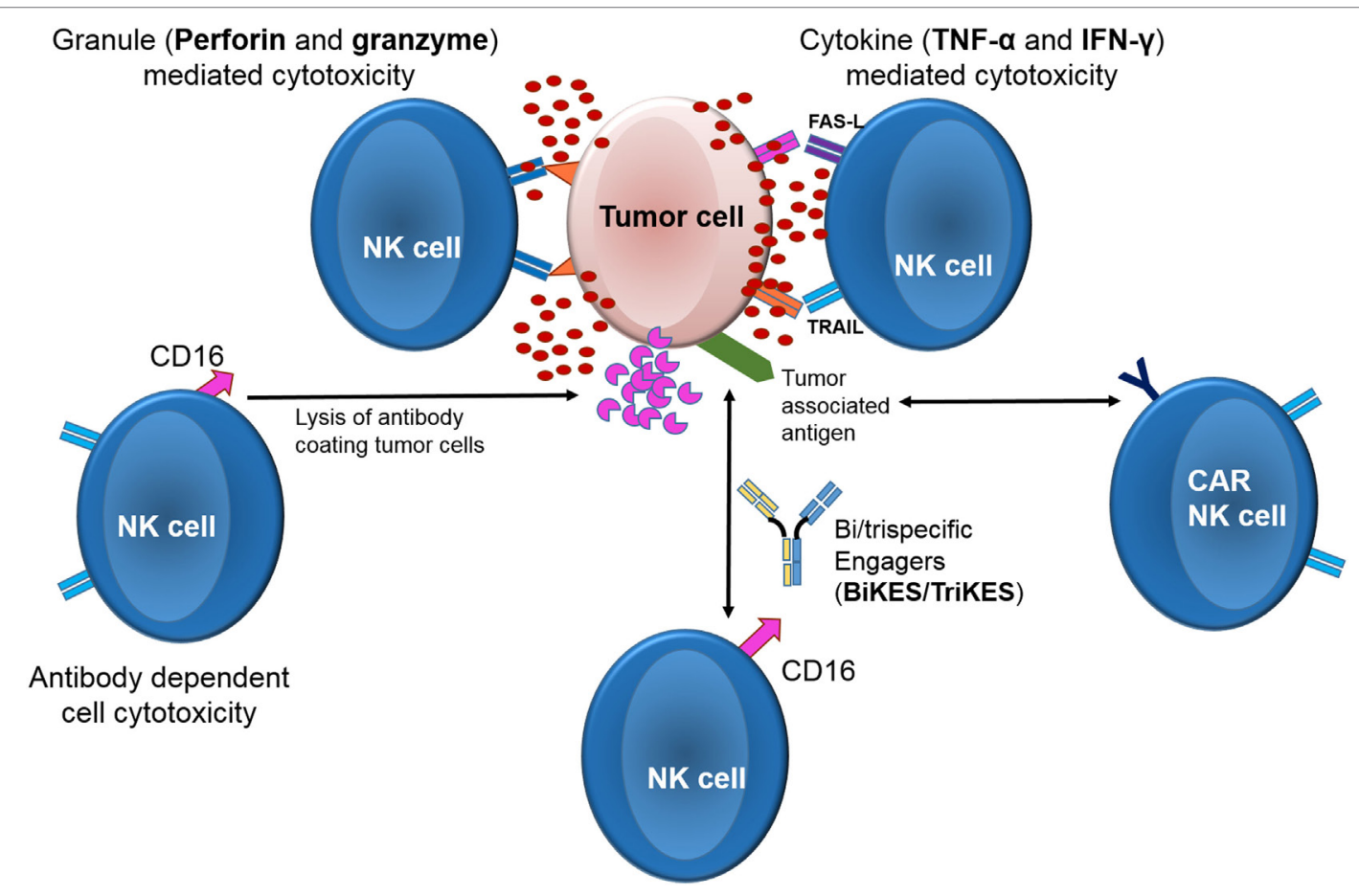

FIGURE 1 | Mechanisms of action of natural killer cell cytotoxicity. 
T cells, it is theoretically less likely for tumor cells to escape NK immunosurveillance even if they downregulate the CAR target antigen (75). This unique property of NK cells could be further exploited for the generation of NK-CARs by selecting donors based on the donor-recipient KIR-ligand mismatch, or based on donor haplotype B KIR gene content, as both have been shown to be beneficial in the setting of allogeneic $\operatorname{HSCT}(48,50,55,76)$. Thus, allogeneic NK cells offer the potential for an off-the-shelf cellular product for immunotherapy that could be readily available for immediate clinical use, in contrast to the current shortage of CAR T-cell products at many centers (77).

\section{SOURCE OF NK CELLS FOR ADOPTIVE IMMUNOTHERAPY}

Functional NK cells can be generated from numerous sources. Although autologous NK cells can be utilized for adoptive therapy, their efficacy against autologous cancer cells is rather limited $(63-71,78,79)$, which we have shown may not be easily overcome by CAR engineering (80). Allogeneic NK cell sources include peripheral blood (PB), bone marrow (BM), human embryonic stem cells (hESCs), induced pluripotent stem cells (iPSCs) (81-83), umbilical CB, or readily available NK cell lines (84). Obtaining NK cells from the PB by apheresis or from BM by harvesting are both cumbersome and are associated with potential risks to the healthy donors (85-87). NK cell derivation from hESCs or iPSCs (81-83) is a complex process and the field is still evolving. In contrast, NK cell lines such as NK-92 (88-93), KHYG-1 (94), NKL, NKG, and YT, to name a few, provide an easily accessible and homogeneous source of cells for the generation of large numbers of CAR-transduced NK cells. NK-92 is a highly cytotoxic NK cell line that was derived from a patient with NK lymphoma (95) and is characterized as CD56 $6^{\text {bright }} \mathrm{CD} 16^{\text {neg/low }} \mathrm{NK}-$ G2A $\mathrm{A}^{\text {positive }}$ and $\mathrm{KIR}^{\text {negative }}$ (except for KIR2DL4) $(96,97)$. Phase I clinical studies demonstrated the safety of NK-92 cell infusion in cancer patients, even up to doses of $10^{10}$ cells $/ \mathrm{m}^{2}(98-100)$. Based on these data, there is great interest in CAR-engineered NK-92 cells for clinical use (Table 1) (88-92, 101-115). However,

\begin{tabular}{lllll} 
TABLE 1 | Clinical trials with NK CAR. & & \\
\hline $\begin{array}{l}\text { Clinical trial } \\
\text { identifier }\end{array}$ & $\begin{array}{l}\text { NK cell } \\
\text { source }\end{array}$ & $\begin{array}{l}\text { Target } \\
\text { antigen }\end{array}$ & Disease & $\begin{array}{l}\text { Study } \\
\text { location }\end{array}$ \\
\hline NCT02944162 & $\begin{array}{l}\text { NK-92 cell } \\
\text { line }\end{array}$ & CD33 & AML & China \\
NCT02892695 & $\begin{array}{l}\text { NK-92 cell } \\
\text { line }\end{array}$ & CD19 & $\begin{array}{l}\text { CD19 positive B cell } \\
\text { malignancies }\end{array}$ & China \\
NCT02742727 & $\begin{array}{l}\text { NK-92 cell } \\
\text { line }\end{array}$ & CD7 & $\begin{array}{l}\text { CD7 positive leukemia or } \\
\text { lymphoma }\end{array}$ & China \\
NCT02839954 & $\begin{array}{l}\text { NK-92 cell } \\
\text { line }\end{array}$ & MUC1 & $\begin{array}{l}\text { MUC1 positive solid } \\
\text { tumors (colorectal, gastric, } \\
\text { pancreatic, NSCLC, breast, }\end{array}$ & China \\
glioma) \\
NCT03056339
\end{tabular}

AML, acute myeloid leukemia; MDACC, MD Anderson Cancer Center; NK, natural killer; NSCLC, non-small cell lung cancer.
NK-92 cells have a number of disadvantages that need to be taken into account. First and foremost, NK-92 cells are derived from a patient with NK lymphoma (95) and thus have the potential for tumor engraftment following infusion. Moreover, they are EBVpositive and carry multiple cytogenetic abnormalities resembling those of NK lymphoma (116). Thus, as a safety measure, NK-92 cells must be irradiated before infusion into patients to prevent permanent engraftment. This can negatively impact their in vivo proliferation and persistence, both factors shown to be crucial for the success of cellular therapy in studies with infusion of tumor-infiltrating lymphocytes (117-119) as well as CAR-T cells (3). Indeed, in a study of NK-92 cells engineered with ErbB2/ HER2-CAR, while irradiation had no effect on the in vitro cytotoxicity of CAR-transduced NK92 cells, it negatively impacted their in vivo replication and persistence, with the cells no longer detectable within 7 days of adoptive infusion (109). Of note, NK-92 cells are CD16 (FCRIII $\gamma$ ) negative and cannot mediate antibody-dependent cell cytotoxicity (ADCC), unless genetically modified to express CD16 (120).

Cord blood, on the other hand, is a readily available source of allogeneic NK cells with distinct benefits over related or unrelated adult donors, including the speed of availability (especially since it is available as an off-the-shelf frozen product) and tolerance of HLA mismatches, the latter of which expands the donor pool. The frequencies of NK cells in CB $(\sim 15-20 \%)$ are similar to PB ( 10-15\%) (121-124). However, until recently the small volume of blood in a CB unit made it challenging to obtain adequate numbers of NK cells for clinical use. Moreover, resting CB NK cells are phenotypically and functionally immature, with higher expression of the inhibitory receptor NKG2A and lower expression of activating and maturation receptors such as NKp46, NKG2C, DNAM-1 (124), and CD57 (124-127). To overcome these limitations, our group has developed a Good Manufacturing Practice (GMP)-compliant procedure, using GMP-grade K562-based artificial antigen-presenting cells (aAPCs) expressing membrane bound IL-21 and 4-1BB ligand, which reliably generates clinically relevant doses of GMP-grade NK cells from a CB unit for adoptive immunotherapy (128). Following ex vivo activation and expansion, CB-derived NK cells display the full array of activating and inhibitory receptors, strongly express eomesodermin (Eomes) and T-bet, two factors necessary for NK cell maturation, and exert similar cytotoxicity to PB-NK cells $(129,130)$. Taken together, these studies support the use of NK cells as a source of cellular therapy in cancer.

\section{Constituents of CAR}

A CAR construct consists of three components: an extracellular antigen-recognition part, a transmembrane domain and an intracellular signaling domain. The extracellular domain is the antigen-recognition site and is generally composed of an $\mathrm{scFv}$ derived from the variable regions of both the heavy and light chains of a monoclonal antibody, fused together via a flexible linker. Most scFvs studied to date are of murine origin, with the potential to induce a human antimouse antibody (HAMA) or an anti-idiotype immune response. A number of investigators are exploring strategies to humanize scFVs (131-136) to circumvent induction of HAMA; however, this approach will 
not prevent the development of anti-idiotype antibodies. The antigen binding domain of a CAR is linked to a "hinge" which imparts flexibility for adequate orientation and binding to the antigen. The hinge binds the extracellular component to a transmembrane domain, which is the link to the intracellular signaling component (137-139). The size of the hinge region has been shown to affect CAR-T cell function, with some studies reporting superior anti-tumor activity of CAR T-cells expressing a shorter hinge $(140,141)$. The transmembrane domain lies between the hinge and the signaling endodomains. Different types of transmembrane domains have been studied, including the CD3- $\zeta$ chain of the T-cell receptor, CD4, CD8, or CD28. The type of transmembrane domain has also been shown to affect the function and stability of the CAR molecule in T cells (142). The endodomain then transmits activation signals to T cells. The "first-generation" CARs used a single intracellular signaling domain (CD3- $\zeta$ chain alone) while the second- and third-generation CARs incorporate one or more additional costimulatory signaling domains, such as CD28, CD137, or OX40 to render them more potent $(143,144)$.

$\mathrm{CD} 3 \zeta$ is critical for signaling and activation of both $\mathrm{T}$ and NK cells (145). In NK cells, CD3 $\zeta$ homodimer transmits signals from Fc $\gamma$ RIII (CD16), thus aiding in ADCC (146). Although CD28 is one of the most commonly employed costimulatory domains in CAR T cells, except in certain cell lines (147), its role in NK cell function is less clearly defined (148). Nonetheless, its addition to $\mathrm{CD} 3 \zeta$ in a second generation ErbB2-specific NK-92 CAR led to improved function compared to a CD3 $\zeta$ construct alone and was similar to that of CD137-CD3 $\zeta$ CAR against ErbB2-expressing tumor cells (109). Another study showed that NK-92 cells transduced with a CD19-CAR expressing CD28$\mathrm{CD} 3 \zeta$ had superior cytotoxicity against CD19-positive targets compared to cells expressing a CD137-CD3 $\zeta$ containing CAR (88). DNAX-activation protein 12 (DAP12) is transmembrane protein involved in signal transduction of several $\mathrm{NK}$ cell activating receptors including NKG2C, NKp44, and the activating KIRs (149). One study tested if a CAR against prostate stem cell antigen (PSCA) that used DAP12 as an intracellular signaling domain can provide sufficient signaling to induce NK cell activation when compared to a CD3 $\zeta$-containing CAR. The authors transduced YTS-NK cells and primary NK cells with PSCA-DAP12 CAR and noted superior cytotoxicity when compared to NK cells expressing a CD3ל-based CAR (150). While the importance of incorporating costimulatory molecules in the CAR construct has been clearly shown for CAR T cells $(4,5,151)$, additional studies are needed to define the optimal costimulatory molecule and signaling endodomain for NK cells.

\section{CAR Transduction}

The incorporation of a foreign gene into a cell requires the use of a vector, which can be based on viral or non-viral systems. The most commonly used tools for CAR gene delivery include genetically engineered retroviruses [lentiviral (152) and gamma-retroviral (153) vectors]. Lentiviruses have the advantage that they are capable of infecting both dividing and non-dividing cells, while retroviruses only infect dividing cells. Therefore, lentiviral vectors can be used for transduction of a wider variety of cell types including quiescent stem cells (154-156). In addition, lentiviral vectors can accommodate larger transgenes when compared with retroviral vectors (157). Insertional mutagenesis, although extremely rare, remains a concern with viral vectors although its likelihood is influenced by a number of factors such as the specific type of vector used and the site of integration (158). For instance, in earlier trials of gene therapy with $\mathrm{CD} 34^{+}$hematopoietic cells for X-linked severe combined immunodeficiency (SCID), 2 of the 10 treated children developed acute leukemia in one study (159) and 1 of the 4 children in another study (160). However, none of the subsequent trials of gene-modified hematopoietic stem cells in SCID children (161) or studies of adoptive immunotherapy with CAR T-cells $(2,3,5,9,162)$ have witnessed adverse events related to insertional mutagenesis to date. Yet, to mitigate any theoretical concerns, various non-viral techniques such as the transposon/transposase system $(82,163)$ or mRNA transfection $(113,115)$ have also been tested. The transduction efficiency using these techniques varies remarkably from study to study $(82,113,115,163,164)$ and depends on a number of factors, including the cell source $(82,113,115,163-167)$. In general, the transduction efficiency for CAR T cells is about $50 \%$ but can range up to $90 \%$ or higher $(152,164,168)$.

\section{CHALLENGES}

Despite the many advantages of NK cells, there are several impediments to the successful generation of CAR NK cells for clinical use. Until recently, the genetic engineering of NK cells, even with viral methods, had proved challenging, with reports of $<10 \%$ transduction efficiency for primary CB or PB derived NK cells $(113,165)$. However, recent optimization in protocols for viral transduction and electroporation $(166,167)$ has revived enthusiasm for the genetic engineering of NK cells. While viral methods appear to be largely ineffective for inducing CAR expression in freshly isolated PB NK cells, significantly better transduction efficiency can be achieved when NK cells from $\mathrm{PB}$ (12-73\%) (113) or CB are activated and expanded (median 69\%; range 43-93\%) (169) in one study and 80\% (range 67-96\%) (170) in another study. In contrast to studies with primary NK cells, NK92 cells are easier to transduce with mRNA electroporation $(113,115)$, with efficiencies averaging from 25 to 50\% (171). However, as the mRNA transcript is not incorporated into the genome, expression of the CAR molecule is often short-lived and detectable for only a few days, which may negatively impact the efficacy of the engineered cells following adoptive transfer (115, 166, 167).

Another concern with using allogeneic NK cells is the possibility of infusing contaminating $\mathrm{T}$ or $\mathrm{B}$ cells in the expanded NK cell product, which can theoretically cause GVHD or posttransplant lymphoproliferative disease, respectively. As some degree of HLA-mismatch after CB transplantation is well tolerated, the risk of clinically significant GVHD may be less with CB-derived CAR-NK cells compared to PB. Plus, with the exception of one study reporting GVHD following adoptive transfer of donor-derived IL-15/4-1BBL-activated NK cells in recipients 
of HLA-matched, T-cell-depleted PB HSCT (72), clinical studies of haploidentical and CB NK cell infusions in hundreds of patients with both hematologic and solid malignancies have not reported a higher risk of GVHD (56, 58, 128, 172-174). Rather, experimental evidence obtained in mice have reported reduced risk of GVHD with NK cells via multiple mechanisms, including depletion of host antigen-presenting cells and activated alloreactive $\mathrm{T}$ cells $(46,72,175,176)$. Another potential limitation of NK cells for immunotherapy is that in contrast to T cells, they are highly sensitive to the freeze and thaw process and they lose activity after thawing. A number of groups are exploring strategies to optimally cryopreserve NK cells and have shown that the activity of frozen NK cells can be restored by overnight incubation with cytokines such as IL-2 (177-182). It is not yet known if a similar strategy can be used to restore function of frozen CAR NK cells for adoptive therapy.

Another characteristic of NK is that they do not persist after adoptive transfer without cytokine support (183). While the shorter life-span of NK cells may be advantageous, allowing for antitumor activity while reducing the probability of long-term adverse events such as prolonged cytopenias caused by ontarget/off-tumor toxicity to normal tissues, it may also limit their efficacy. For in vivo survival and proliferation, NK cells require continuous cytokine support, without which they are detectable in the circulation for only 1-2 weeks (183). The two most commonly used cytokines to support the persistence of adoptively transferred NK cells are IL-2 and IL-15 $(184,185)$. The infusion of IL-2 has substantial side effects including fevers, chills, myalgias and capillary leak syndrome (186), and can promote expansion of regulatory $\mathrm{T}$ cells $\left(\mathrm{T}_{\text {regs }}\right)$ which are suppressive to NK cells (187). IL-15, on the other hand, does not support $\mathrm{T}_{\text {reg }}$ (188) expansion but when administered as an exogenous bolus to patients with metastatic melanoma and renal carcinoma can result in dose-dependent toxicity, including neutropenia (189). An alternative approach to exogenous administration of cytokines is to treat patients with lymphodepleting chemotherapy such as cyclophosphamide and fludarabine prior to infusion of NK cells, which provides a favorable environment for NK cell expansion by depleting mature lymphocytes (which consume IL-15), resulting in a marked increase in endogenous IL-15 levels (56). Another novel technique is to incorporate genes for IL-2 (104, 190-192) or IL-15 (80, 193-195) within the CAR construct to constantly provide cytokine support to the CAR-transduced cells. We recently showed the feasibility and efficacy of this approach in a mouse model of Raji lymphoma. Although a single infusion of $1 \times 10^{7}$ CAR.19+ (without IL15) or CAR.19/IL15 ${ }^{+}$CB-NK cells both improved tumor control and prolonged survival compared to non-transduced CB-NK, CAR.19/IL15 ${ }^{+}$CB-NK cells controlled tumor expansion and prolonged survival significantly better than the CAR.CD19 construct lacking the $I L-15$ gene, which underscores the critical influence of IL-15 in enhancing antitumor activity in vivo (80).

\section{SUICIDE GENES}

Given the recent safety concerns such as cytokine release syndrome and neurotoxicity associated with infusion of
CAR-modified T cells $(196,197)$ (and possibly NK cells), careful consideration of whether a suicide system should be incorporated into the construct as a safety measure is needed. One of the most extensively tested safety switches include the herpes simplex virus thymidine kinase gene $(198,199)$. While a number of studies have tested this approach, the highly immunogenic virus-derived protein can lead to the rejection of cells expressing it, plus it requires administration of ganciclovir-which takes several days to work and leads to cytopenias (200-202). Because of these disadvantages, inducible caspase-9 (iCasp9) has emerged as one of the most commonly used suicide genes in adoptive cell therapy trials $(80,193,203-206)$. When exposed to a synthetic bioinert small-molecule dimerizing drug, the iCasp9 becomes activated and leads to rapid apoptosis of cells expressing it. Another suicide gene under investigation is the truncated epidermal growth factor receptor (EGFR), which lacks intracellular tyrosine kinase activity while expressing an intact binding epitope that can be targeted with the anti-EGFR monoclonal antibody cetuximab for the rapid elimination of the transgenic cells $(207,208)$.

\section{Preclinical Studies of CAR-NK Cells}

Building on the knowledge gained with CAR T-cells, a multitude of preclinical studies have tested the efficacy of CAR NK cells against a variety of target antigens for hematological malignancies such as CD19 (167, 169), CD20 (209, 210), CD138 (211), CS1 (111), CD3 (212), CD5 (101), CD123 (213), as well as solid tumors such as HER-2/Erb-2 (109, 214-216), GD2 (114), EpCAM (195), EGFR and mutant EGFRvIII (89), WT1 (217), and ROR-1 (218) to name a few. An alternative and non-antigen specific approach to engineering NK cells was tested by Chang et al. (170), where the authors induced supra-physiologic expression of NKG2D, a key receptor for NK cell activation and signal transduction via DNAX-activating protein 10 (DAP10). Ex vivo expanded $\mathrm{PB}$ NK cells transduced with a retroviral vector encoding NKG2DDAP10-CD3 $\zeta$ showed impressive in vivo cytotoxicity in xenogeneic mouse models of hematologic and solid tumors but showed no activity against non-transformed blood or mesenchymal cells (170).

Despite these impressive preclinical data, there are currently only five registered clinical trials testing the safety and efficacy of CAR-NK cells in cancer patients (Table 1). Four of these trials are being conducted in China using the CAR-engineered NK92 cells. The only trial using primary NK cells (CB NK cells) is being conducted in the United States by our group at the MD Anderson Cancer Center (NCT03056339). Patients with relapsed or refractory $\mathrm{CD} 19^{+} \mathrm{B}$ cell lymphoid malignancies are eligible for this trial. All patients receive lymphodepleting chemotherapy with fludarabine and cyclophosphamide, followed by the infusion of allogeneic CB-derived NK cells that are genetically modified with a retroviral vector, iC9-2A-CAR.CD19-CD28-CD3zeta-2AOhIL-15 (iC9/CAR.19/IL15) (80), which (i) includes CAR.19gene to redirect specificity to CD19; (ii) produces IL-15 ectopically-a cytokine crucial for NK cell survival and proliferation (219); and (iii) incorporates inducible caspase-9 (iCasp9) - a suicide gene, which can be activated pharmacologically to eliminate CAR cells, as needed $(203,219)$. 


\section{CONCLUSION}

We are in an exciting era in the field of cellular therapy. NK cells hold great promise and offer the potential for an off-the-shelf cellular product for immunotherapy that could be readily available for immediate clinical use. Yet, before NK cells can be extended to larger cohorts of patients a number of scientific questions and regulatory hurdles must be addressed. What is the ideal vector, signaling endodomain and costimulatory molecule for NK cells-one with the best response and safety profile? Will CAR NK cells have a different safety and efficacy profile to CAR T cells, given their distinct mechanism of action? Will "off-the-shelf" CAR NK cells be able to sustain the clinical demand, give the shortage of CAR-T cells at many centers and the uncertainty regarding the health economics of this treatment? Can CAR NK cells lead to durable responses,

\section{REFERENCES}

1. Kochenderfer JN, Wilson WH, Janik JE, Dudley ME, Stetler-Stevenson M, Feldman SA, et al. Eradication of B-lineage cells and regression of lymphoma in a patient treated with autologous $\mathrm{T}$ cells genetically engineered to recognize CD19. Blood (2010) 116(20):4099-102. doi:10.1182/blood-2010-04281931

2. Porter DL, Levine BL, Kalos M, Bagg A, June CH. Chimeric antigen receptor-modified T cells in chronic lymphoid leukemia. N Engl J Med (2011) 365(8):725-33. doi:10.1056/NEJMoa1103849

3. Porter DL, Hwang WT, Frey NV, Lacey SF, Shaw PA, Loren AW, et al. Chimeric antigen receptor $\mathrm{T}$ cells persist and induce sustained remissions in relapsed refractory chronic lymphocytic leukemia. Sci Transl Med (2015) 7(303):303ra139. doi:10.1126/scitranslmed.aac5415

4. Lee DW, Kochenderfer JN, Stetler-Stevenson M, Cui YK, Delbrook C, Feldman SA, et al. T cells expressing CD19 chimeric antigen receptors for acute lymphoblastic leukaemia in children and young adults: a phase 1 dose-escalation trial. Lancet (2015) 385(9967):517-28. doi:10.1016/ S0140-6736(14)61403-3

5. Maude SL, Frey N, Shaw PA, Aplenc R, Barrett DM, Bunin NJ, et al. Chimeric antigen receptor $\mathrm{T}$ cells for sustained remissions in leukemia. $N$ Engl J Med (2014) 371(16):1507-17. doi:10.1056/NEJMoa1407222

6. Davila ML, Riviere I, Wang X, Bartido S, Park J, Curran K, et al. Efficacy and toxicity management of $19-28 z$ CAR T cell therapy in B cell acute lymphoblastic leukemia. Sci Transl Med (2014) 6(224):224ra25. doi:10.1126/ scitranslmed.3008226

7. Li Z, Chen L, Rubinstein MP. Cancer immunotherapy: are we there yet? Exp Hematol Oncol (2013) 2(1):33. doi:10.1186/2162-3619-2-33

8. Brentjens RJ, Davila ML, Riviere I, Park J, Wang X, Cowell LG, et al. CD19-targeted $\mathrm{T}$ cells rapidly induce molecular remissions in adults with chemotherapy-refractory acute lymphoblastic leukemia. Sci Transl Med (2013) 5(177):177ra38. doi:10.1126/scitranslmed.3005930

9. Grupp SA, Kalos M, Barrett D, Aplenc R, Porter DL, Rheingold SR, et al. Chimeric antigen receptor-modified T cells for acute lymphoid leukemia. $N$ Engl J Med (2013) 368(16):1509-18. doi:10.1056/NEJMoa1215134

10. Irving BA, Weiss A. The cytoplasmic domain of the $\mathrm{T}$ cell receptor zeta chain is sufficient to couple to receptor-associated signal transduction pathways. Cell (1991) 64(5):891-901. doi:10.1016/0092-8674(91)90314-O

11. Gross G, Waks T, Eshhar Z. Expression of immunoglobulin-T-cell receptor chimeric molecules as functional receptors with antibody-type specificity. Proc Natl Acad Sci U S A (1989) 86(24):10024-8. doi:10.1073/pnas.86. 24.10024

12. Luo Y, Chang L-J, Hu Y, Dong L, Wei G, Huang H. First-in-man CD123specific chimeric antigen receptor-modified $\mathrm{T}$ cells for the treatment of refractory acute myeloid leukemia. Blood (2015) 126:3778.

13. Ritchie DS, Neeson PJ, Khot A, Peinert S, Tai T, Tainton K, et al. Persistence and efficacy of second generation CAR T cell against the LeY antigen in acute myeloid leukemia. Mol Ther (2013) 21(11):2122-9. doi:10.1038/mt.2013.154 considering their limited in vivo life-span or will they be used as a "bridge" to more aggressive treatment such as HSCT? Based on the results of haploidentical and unrelated donor HSCT, should NK cells for CAR modification be selected based on KIR-KIR ligand mismatch or KIR haplotype to harness their native NK cell activity and will this approach reduce the risk of disease escape through downregulation of the CAR target antigen? With the plethora of preclinical studies and clinical research that are underway, it is expected that engineered NK cells will make a significant contribution to the recent paradigm shift in cancer treatment.

\section{AUTHOR CONTRIBUTIONS}

$\mathrm{RM}$ and KR reviewed the literature, analyzed data, and wrote the manuscript.

14. Wang QS, Wang Y, Lv HY, Han QW, Fan H, Guo B, et al. Treatment of CD33-directed chimeric antigen receptor-modified $\mathrm{T}$ cells in one patient with relapsed and refractory acute myeloid leukemia. Mol Ther (2015) 23(1):184-91. doi:10.1038/mt.2014.164

15. Goulmy E. Human minor histocompatibility antigens: new concepts for marrow transplantation and adoptive immunotherapy. Immunol Rev (1997) 157:125-40. doi:10.1111/j.1600-065X.1997.tb00978.x

16. Davies JOJ, Stringaris K, Barrett AJ, Rezvani K. Opportunities and limitations of natural killer cells as adoptive therapy for malignant disease. Cytotherapy (2014) 16(11):1453-66. doi:10.1016/j.jcyt.2014.03.009

17. Vivier E, Ugolini S, Blaise D, Chabannon C, Brossay L. Targeting natural killer cells and natural killer T cells in cancer. Nat Rev Immunol (2012) 12(4):239-52. doi:10.1038/nri3174

18. Lanier LL. NK cell receptors. Annu Rev Immunol (1998) 16:359-93. doi:10.1146/annurev.immunol.16.1.359

19. Caligiuri MA. Human natural killer cells. Blood (2008) 112(3):461-9. doi:10.1182/blood-2007-09-077438

20. Parham P. MHC class I molecules and KIRs in human history, health and survival. Nat Rev Immunol (2005) 5(3):201-14. doi:10.1038/nri1570

21. Moretta L, Moretta A. Killer immunoglobulin-like receptors. Curr Opin Immunol (2004) 16(5):626-33. doi:10.1016/j.coi.2004.07.010

22. Farag SS, Fehniger TA, Ruggeri L, Velardi A, Caligiuri MA. Natural killer cell receptors: new biology and insights into the graft-versus-leukemia effect. Blood (2002) 100(6):1935-47. doi:10.1182/blood-2002-02-0350

23. Moretta A, Bottino C, Vitale M, Pende D, Cantoni C, Mingari MC, et al. Activating receptors and coreceptors involved in human natural killer cell-mediated cytolysis. Annu Rev Immunol (2001) 19:197-223. doi:10.1146/ annurev.immunol.19.1.197

24. Lanier LL. Face off - the interplay between activating and inhibitory immune receptors. Curr Opin Immunol (2001) 13(3):326-31. doi:10.1016/ S0952-7915(00)00222-3

25. Yokoyama WM. Natural killer cell receptors. Curr Opin Immunol (1998) 10(3):298-305. doi:10.1016/S0952-7915(98)80168-4

26. Ljunggren HG, Karre K. In search of the 'missing self': MHC molecules and NK cell recognition. Immunol Today (1990) 11(7):237-44. doi:10.1016/0167-5699(90)90097-S

27. Harel-Bellan A, Quillet A, Marchiol C, DeMars R, Tursz T, Fradelizi D. Natural killer susceptibility of human cells may be regulated by genes in the HLA region on chromosome 6. Proc Natl Acad Sci U S A (1986) 83(15):5688-92. doi:10.1073/pnas.83.15.5688

28. Algarra I, Garcia-Lora A, Cabrera T, Ruiz-Cabello F, Garrido F. The selection of tumor variants with altered expression of classical and nonclassical MHC class I molecules: implications for tumor immune escape. Cancer Immunol Immunother (2004) 53(10):904-10. doi:10.1007/s00262-004-0517-9

29. Costello RT, Gastaut JA, Olive D. Tumor escape from immune surveillance. Arch Immunol Ther Exp (Warsz) (1999) 47(2):83-8.

30. Robertson MJ, Ritz J. Biology and clinical relevance of human natural killer cells. Blood (1990) 76(12):2421-38. 
31. Cooper MA, Fehniger TA, Caligiuri MA. The biology of human natural killer-cell subsets. Trends Immunol (2001) 22(11):633-40. doi:10.1016/ S1471-4906(01)02060-9

32. Fehniger TA, Cooper MA, Nuovo GJ, Cella M, Facchetti F, Colonna M, et al. CD56bright natural killer cells are present in human lymph nodes and are activated by T cell-derived IL-2: a potential new link between adaptive and innate immunity. Blood (2003) 101(8):3052-7. doi:10.1182/ blood-2002-09-2876

33. Yokoyama WM. Natural killer cell receptors. Curr Opin Immunol (1995) 7(1):110-20. doi:10.1016/0952-7915(95)80036-0

34. Brandt CS, Baratin M, Yi EC, Kennedy J, Gao Z, Fox B, et al. The B7 family member B7-H6 is a tumor cell ligand for the activating natural killer cell receptor NKp30 in humans. J Exp Med (2009) 206(7):1495-503. doi:10.1084/ jem.20090681

35. Pogge von Strandmann E, Simhadri VR, von Tresckow B, Sasse S, Reiners KS, Hansen HP, et al. Human leukocyte antigen-B-associated transcript 3 is released from tumor cells and engages the NKp30 receptor on natural killer cells. Immunity (2007) 27(6):965-74. doi:10.1016/j.immuni.2007.10.010

36. Bloushtain N, Qimron U, Bar-Ilan A, Hershkovitz O, Gazit R, Fima E, et al. Membrane-associated heparan sulfate proteoglycans are involved in the recognition of cellular targets by NKp30 and NKp46. J Immunol (2004) 173(4):2392-401. doi:10.4049/jimmunol.173.4.2392

37. Jinushi M, Takehara T, Tatsumi T, Kanto T, Groh V, Spies T, et al. Expression and role of MICA and MICB in human hepatocellular carcinomas and their regulation by retinoic acid. Int J Cancer (2003) 104(3):354-61. doi:10.1002/ ijc.10966

38. Boyington JC, Sun PD. A structural perspective on MHC class I recognition by killer cell immunoglobulin-like receptors. Mol Immunol (2002) 38(14):1007-21. doi:10.1016/S0161-5890(02)00030-5

39. Boyington JC, Brooks AG, Sun PD. Structure of killer cell immunoglobulin-like receptors and their recognition of the class I MHC molecules. Immunol Rev (2001) 181:66-78. doi:10.1034/j.1600-065X.2001.1810105.x

40. Steinle A, Li P, Morris DL, Groh V, Lanier LL, Strong RK, et al. Interactions of human NKG2D with its ligands MICA, MICB, and homologs of the mouse RAE-1 protein family. Immunogenetics (2001) 53(4):279-87. doi:10.1007/ s002510100325

41. Das H, Groh V, Kuijl C, Sugita M, Morita CT, Spies T, et al. MICA engagement by human Vgamma2Vdelta2 $\mathrm{T}$ cells enhances their antigen-dependent effector function. Immunity (2001) 15(1):83-93. doi:10.1016/S10747613(01)00168-6

42. Cosman D, Müllberg J, Sutherland CL, Chin W, Armitage R, Fanslow W, et al. ULBPs, novel MHC class I-related molecules, bind to CMV glycoprotein UL16 and stimulate NK cytotoxicity through the NKG2D receptor. Immunity (2001) 14(2):123-33. doi:10.1016/S1074-7613(01)00095-4

43. Bauer S, Groh V, Wu J, Steinle A, Phillips JH, Lanier LL, et al. Activation of NK cells and T cells by NKG2D, a receptor for stress-inducible MICA. Science (1999) 285(5428):727-9. doi:10.1126/science.285.5428.727

44. Gumperz JE, Barber LD, Valiante NM, Percival L, Phillips JH, Lanier LL, et al. Conserved and variable residues within the Bw4 motif of HLA-B make separable contributions to recognition by the NKB1 killer cell-inhibitory receptor. J Immunol (1997) 158(11):5237-41.

45. Mandelboim O, Reyburn HT, Sheu EG, Vales-Gomez M, Davis DM, Pazmany L, et al. The binding site of NK receptors on HLA-C molecules. Immunity (1997) 6(3):341-50. doi:10.1016/S1074-7613(00)80336-2

46. Ruggeri L, Capanni M, Urbani E, Perruccio K, Shlomchik WD, Tosti A, et al. Effectiveness of donor natural killer cell alloreactivity in mismatched hematopoietic transplants. Science (2002) 295(5562):2097-100. doi:10.1126/ science. 1068440

47. Ruggeri L, Capanni M, Casucci M, Volpi I, Tosti A, Perruccio K, et al. Role of natural killer cell alloreactivity in HLA-mismatched hematopoietic stem cell transplantation. Blood (1999) 94(1):333-9.

48. Cooley S, Trachtenberg E, Bergemann TL, Saeteurn K, Klein J, Le CT, et al. Donors with group B KIR haplotypes improve relapse-free survival after unrelated hematopoietic cell transplantation for acute myelogenous leukemia. Blood (2009) 113(3):726-32. doi:10.1182/blood-2008-07-171926

49. Oevermann L, Michaelis SU, Mezger M, Lang P, Toporski J, Bertaina A, et al. KIR B haplotype donors confer a reduced risk for relapse after haploidentical transplantation in children with ALL. Blood (2014) 124(17):2744-7. doi:10.1182/blood-2014-03-565069
50. Cooley S, Weisdorf DJ, Guethlein LA, Klein JP, Wang T, Le CT, et al. Donor selection for natural killer cell receptor genes leads to superior survival after unrelated transplantation for acute myelogenous leukemia. Blood (2010) 116(14):2411-9. doi:10.1182/blood-2010-05-283051

51. Cooley S, Weisdorf DJ, Guethlein LA, Klein JP, Wang T, Marsh SG, et al. Donor killer cell Ig-like receptor B haplotypes, recipient HLA-C1, and HLA-C mismatch enhance the clinical benefit of unrelated transplantation for acute myelogenous leukemia. JImmunol (2014) 192(10):4592-600. doi:10.4049/jimmunol.1302517

52. Stringaris K, Adams S, Uribe M, Eniafe R, Wu CO, Savani BN, et al. Donor KIR genes 2DL5A, 2DS1 and 3DS1 are associated with a reduced rate of leukemia relapse after HLA-identical sibling stem cell transplantation for acute myeloid leukemia but not other hematologic malignancies. Biol Blood Marrow Transplant (2010) 16(9):1257-64. doi:10.1016/j.bbmt.2010.03.004

53. Willemze R, Ruggeri A, Purtill D, Rodrigues CA, Gluckman E, Rocha V, et al. Is there an impact of killer cell immunoglobulin-like receptors and KIR-ligand incompatibilities on outcomes after unrelated cord blood stem cell transplantation? Best Pract Res Clin Haematol (2010) 23(2):283-90. doi:10.1016/j.beha.2010.05.005

54. Willemze R, Rodrigues CA, Labopin M, Sanz G, Michel G, Socié G, et al. KIR-ligand incompatibility in the graft-versus-host direction improves outcomes after umbilical cord blood transplantation for acute leukemia. Leukemia (2009) 23(3):492-500. doi:10.1038/leu.2008.365

55. Sekine T, Marin D, Cao K, Li L, Mehta P, Shaim H, et al. Specific combinations of donor and recipient KIR-HLA genotypes predict for large differences in outcome after cord blood transplantation. Blood (2016) 128(2):297-312. doi:10.1182/blood-2016-03-706317

56. Miller JS, Soignier Y, Panoskaltsis-Mortari A, McNearney SA, Yun GH, Fautsch SK, et al. Successful adoptive transfer and in vivo expansion of human haploidentical NK cells in patients with cancer. Blood (2005) 105(8):3051-7. doi:10.1182/blood-2004-07-2974

57. Iliopoulou EG, Kountourakis P, Karamouzis MV, Doufexis D, Ardavanis A, Baxevanis $\mathrm{CN}$, et al. A phase I trial of adoptive transfer of allogeneic natural killer cells in patients with advanced non-small cell lung cancer. Cancer Immunol Immunother (2010) 59(12):1781-9. doi:10.1007/s00262-010-0904-3

58. Rubnitz JE, Inaba H, Ribeiro RC, Pounds S, Rooney B, Bell T, et al. NKAML: a pilot study to determine the safety and feasibility of haploidentical natural killer cell transplantation in childhood acute myeloid leukemia. J Clin Oncol (2010) 28(6):955-9. doi:10.1200/JCO.2009.24.4590

59. Curti A, Ruggeri L, D’Addio A, Bontadini A, Dan E, Motta MR, et al. Successful transfer of alloreactive haploidentical KIR ligand-mismatched natural killer cells after infusion in elderly high risk acute myeloid leukemia patients. Blood (2011) 118(12):3273-9. doi:10.1182/blood-2011-01329508

60. Geller MA, Cooley S, Judson PL, Ghebre R, Carson LF, Argenta PA, et al. A phase II study of allogeneic natural killer cell therapy to treat patients with recurrent ovarian and breast cancer. Cytotherapy (2011) 13(1):98-107. doi:1 0.3109/14653249.2010.515582

61. Bachanova V, Cooley S, Defor TE, Verneris MR, Zhang B, McKenna DH, et al. Clearance of acute myeloid leukemia by haploidentical natural killer cells is improved using IL-2 diphtheria toxin fusion protein. Blood (2014) 123(25):3855-63. doi:10.1182/blood-2013-10-532531

62. Shaffer BC, Le Luduec JB, Forlenza C, Jakubowski AA, Perales MA, Young JW, et al. Phase II study of haploidentical natural killer cell infusion for treatment of relapsed or persistent myeloid malignancies following allogeneic hematopoietic cell transplantation. Biol Blood Marrow Transplant (2016) 22(4):705-9. doi:10.1016/j.bbmt.2015.12.028

63. Soiffer RJ, Murray C, Cochran K, Cameron C, Wang E, Schow PW, et al. Clinical and immunologic effects of prolonged infusion of low-dose recombinant interleukin-2 after autologous and T-cell-depleted allogeneic bone marrow transplantation. Blood (1992) 79(2):517-26.

64. Caligiuri MA, Murray C, Robertson MJ, Wang E, Cochran K, Cameron C, et al. Selective modulation of human natural killer cells in vivo after prolonged infusion of low dose recombinant interleukin 2. J Clin Invest (1993) 91(1):123-32. doi:10.1172/JCI116161

65. Weisdorf DJ, Anderson PM, Blazar BR, Uckun FM, Kersey JH, Ramsay NK. Interleukin 2 immediately after autologous bone marrow transplantation for acute lymphoblastic leukemia - a phase I study. Transplantation (1993) 55(1):61-6. doi:10.1097/00007890-199301000-00012 
66. Lister J, Rybka WB, Donnenberg AD, deMagalhaes-Silverman M, Pincus SM, Bloom EJ, et al. Autologous peripheral blood stem cell transplantation and adoptive immunotherapy with activated natural killer cells in the immediate posttransplant period. Clin Cancer Res (1995) 1(6):607-14.

67. Meropol NJ, Porter M, Blumenson LE, Lindemann MJ, Perez RP, Vaickus L, et al. Daily subcutaneous injection of low-dose interleukin 2 expands natural killer cells in vivo without significant toxicity. Clin Cancer Res (1996) 2(4):669-77.

68. Blaise D, Attal M, Pico JL, Reiffers J, Stoppa AM, Bellanger C, et al. The use of a sequential high dose recombinant interleukin 2 regimen after autologous bone marrow transplantation does not improve the disease free survival of patients with acute leukemia transplanted in first complete remission. Leuk Lymphoma (1997) 25(5-6):469-78. doi:10.3109/10428199709039034

69. Miller JS, Tessmer-Tuck J, Pierson BA, Weisdorf D, McGlave P, Blazar BR, et al. Low dose subcutaneous interleukin-2 after autologous transplantation generates sustained in vivo natural killer cell activity. Biol Blood Marrow Transplant (1997) 3(1):34-44.

70. deMagalhaes-Silverman M, Donnenberg A, Lembersky B, Elder E, Lister J, Rybka W, et al. Posttransplant adoptive immunotherapy with activated natural killer cells in patients with metastatic breast cancer. J Immunother (2000) 23(1):154-60. doi:10.1097/00002371-200001000-00018

71. Burns LJ, Weisdorf DJ, DeFor TE, Vesole DH, Repka TL, Blazar BR, et al. IL-2-based immunotherapy after autologous transplantation for lymphoma and breast cancer induces immune activation and cytokine release: a phase I/II trial. Bone Marrow Transplant (2003) 32(2):177-86. doi:10.1038/sj.bmt. 1704086

72. Olson JA, Leveson-Gower DB, Gill S, Baker J, Beilhack A, Negrin RS. NK cells mediate reduction of GVHD by inhibiting activated, alloreactive T cells while retaining GVT effects. Blood (2010) 115(21):4293-301. doi:10.1182/ blood-2009-05-222190

73. Ruggeri L, Mancusi A, Burchielli E, Capanni M, Carotti A, Aloisi T, et al. NK cell alloreactivity and allogeneic hematopoietic stem cell transplantation. Blood Cells Mol Dis (2008) 40(1):84-90. doi:10.1016/j.bcmd.2007.06.029

74. Kalos M, Nazimuddin F, Finklestein JM, Gupta M, Kulikovskaya I, Ambrose DE, et al. Long-term functional persistence, B cell aplasia and anti-leukemia efficacy in refractory $\mathrm{B}$ cell malignancies following $\mathrm{T}$ cell immunotherapy using CAR-redirected T cells targeting CD19. Blood (2013) 122:163.

75. Sotillo E, Barrett DM, Black KL, Bagashev A, Oldridge D, Wu G, et al. Convergence of acquired mutations and alternative splicing of CD19 enables resistance to CART-19 immunotherapy. Cancer Discov (2015) 5(12):1282-95. doi:10.1158/2159-8290.CD-15-1020

76. Venstrom JM, Pittari G, Gooley TA, Chewning JH, Spellman S, Haagenson M, et al. HLA-C-dependent prevention of leukemia relapse by donor activating KIR2DS1. N Engl J Med (2012) 367(9):805-16. doi:10.1056/NEJMoa1200503

77. Couzin-Frankel J. Supply of promising T cell therapy is strained. Science (2017) 356(6343):1112-3. doi:10.1126/science.356.6343.1112

78. Rouce RH, Shaim H, Sekine T, Weber G, Ballard B, Ku S, et al. The TGF-beta/ SMAD pathway is an important mechanism for NK cell immune evasion in childhood B-acute lymphoblastic leukemia. Leukemia (2016) 30(4):800-11. doi:10.1038/leu.2015.327

79. Stringaris K, Sekine T, Khoder A, Alsuliman A, Razzaghi B, Sargeant R, et al. Leukemia-induced phenotypic and functional defects in natural killer cells predict failure to achieve remission in acute myeloid leukemia. Haematologica (2014) 99(5):836-47. doi:10.3324/haematol.2013.087536

80. Liu E, Tong Y, Dotti G, Shaim H, Savoldo B, Mukherjee M, et al. Cord blood NK cells engineered to express IL-15 and a CD19-targeted CAR show long-term persistence and potent antitumor activity. Leukemia (2018) 32(2):520-31. doi:10.1038/leu.2017.226

81. Ni Z, Knorr DA, Bendzick L, Allred J, Kaufman DS. Expression of chimeric receptor CD4zeta by natural killer cells derived from human pluripotent stem cells improves in vitro activity but does not enhance suppression of HIV infection in vivo. Stem Cells (2014) 32(4):1021-31. doi:10.1002/stem.1611

82. Wilber A, Linehan JL, Tian X, Woll PS, Morris JK, Belur LR, et al. Efficient and stable transgene expression in human embryonic stem cells using transposon-mediated gene transfer. Stem Cells (2007) 25(11):2919-27. doi:10.1634/stemcells.2007-0026

83. Knorr DA, Ni Z, Hermanson D, Hexum MK, Bendzick L, Cooper LJ, et al. Clinical-scale derivation of natural killer cells from human pluripotent stem cells for cancer therapy. Stem Cells Transl Med (2013) 2(4):274-83. doi:10.5966/sctm.2012-0084

84. Matsuo Y, Drexler HG. Immunoprofiling of cell lines derived from natural killer-cell and natural killer-like T-cell leukemia-lymphoma. Leuk Res (2003) 27(10):935-45. doi:10.1016/S0145-2126(03)00024-9

85. Yuan S, Ziman A, Smeltzer B, Lu Q, Goldfinger D. Moderate and severe adverse events associated with apheresis donations: incidences and risk factors. Transfusion (2010) 50(2):478-86. doi:10.1111/j.1537-2995.2009.02443.x

86. Miller JP, Perry EH, Price TH, Bolan CD Jr, Karanes C, Boyd TM, et al. Recovery and safety profiles of marrow and PBSC donors: experience of the National Marrow Donor Program. Biol Blood Marrow Transplant (2008) 14(9 Suppl):29-36. doi:10.1016/j.bbmt.2008.05.018

87. Winters JL. Complications of donor apheresis. JClin Apher (2006) 21(2):132-41. doi:10.1002/jca.20039

88. Oelsner S, Friede ME, Zhang C, Wagner J, Badura S, Bader P, et al. Continuously expanding CAR NK-92 cells display selective cytotoxicity against B-cell leukemia and lymphoma. Cytotherapy (2017) 19(2):235-49. doi:10.1016/j.jcyt.2016.10.009

89. Genssler S, Burger MC, Zhang C, Oelsner S, Mildenberger I, Wagner M, et al. Dual targeting of glioblastoma with chimeric antigen receptor-engineered natural killer cells overcomes heterogeneity of target antigen expression and enhances antitumor activity and survival. Oncoimmunology (2016) 5(4):e1119354. doi:10.1080/2162402X.2015.1119354

90. Chen X, Han J, Chu J, Zhang L, Zhang J, Chen C, et al. A combinational therapy of EGFR-CAR NK cells and oncolytic herpes simplex virus 1 for breast cancer brain metastases. Oncotarget (2016) 7(19):27764-77. doi:10.18632/ oncotarget. 8526

91. Romanski A, Uherek C, Bug G, Seifried E, Klingemann H, Wels WS, et al. CD19-CAR engineered NK-92 cells are sufficient to overcome NK cell resistance in B-cell malignancies. J Cell Mol Med (2016) 20(7):1287-94. doi: $10.1111 /$ jcmm. 12810

92. Zhang C, Burger MC, Jennewein L, Genßler S, Schönfeld K, Zeiner P, et al. ErbB2/HER2-specific NK cells for targeted therapy of glioblastoma. J Natl Cancer Inst (2016) 108(5). doi:10.1093/jnci/djv375

93. Suck G, Odendahl M, Nowakowska P, Seidl C, Wels WS, Klingemann HG, et al. NK-92: an 'off-the-shelf therapeutic' for adoptive natural killer cell-based cancer immunotherapy. Cancer Immunol Immunother (2016) 65(4):485-92. doi:10.1007/s00262-015-1761-x

94. Kobayashi E, Kishi H, Ozawa T, Hamana H, Nakagawa H, Jin A, et al. A chimeric antigen receptor for TRAIL-receptor 1 induces apoptosis in various types of tumor cells. Biochem Biophys Res Commun (2014) 453(4):798-803. doi:10.1016/j.bbrc.2014.10.024

95. Gong JH, Maki G, Klingemann HG. Characterization of a human cell line (NK-92) with phenotypical and functional characteristics of activated natural killer cells. Leukemia (1994) 8(4):652-8.

96. Tonn T, Becker S, Esser R, Schwabe D, Seifried E. Cellular immunotherapy of malignancies using the clonal natural killer cell line NK-92.J Hematother Stem Cell Res (2001) 10(4):535-44. doi:10.1089/15258160152509145

97. Maki G, Klingemann HG, Martinson JA, Tam YK. Factors regulating the cytotoxic activity of the human natural killer cell line, NK-92. J Hematother Stem Cell Res (2001) 10(3):369-83. doi:10.1089/152581601750288975

98. Tonn T, Schwabe D, Klingemann HG, Becker S, Esser R, Koehl U, et al. Treatment of patients with advanced cancer with the natural killer cell line NK-92. Cytotherapy (2013) 15(12):1563-70. doi:10.1016/j.jcyt.2013.06.017

99. Arai S, Meagher R, Swearingen M, Myint H, Rich E, Martinson J, et al. Infusion of the allogeneic cell line NK-92 in patients with advanced renal cell cancer or melanoma: a phase I trial. Cytotherapy (2008) 10(6):625-32. doi:10.1080/14653240802301872

100. Boyiadzis M, Agha M, Redner RL, Sehgal A, Im A, Hou JZ, et al. Phase 1 clinical trial of adoptive immunotherapy using "off-the-shelf" activated natural killer cells in patients with refractory and relapsed acute myeloid leukemia. Cytotherapy (2017) 19(10):1225-32. doi:10.1016/j.jcyt.2017.07.008

101. Chen KH, Wada M, Pinz KG, Liu H, Lin KW, Jares A, et al. Preclinical targeting of aggressive T-cell malignancies using anti-CD5 chimeric antigen receptor. Leukemia (2017) 31(10):2151-60. doi:10.1038/leu.2017.8

102. Wang Z, Guo L, Song Y, Zhang Y, Lin D, Hu B, et al. Augmented anti-tumor activity of NK-92 cells expressing chimeric receptors of TGF-betaR II and NKG2D. Cancer Immunol Immunother (2017) 66(4):537-48. doi:10.1007/ s00262-017-1959-1 
103. Hsieh YT, Aggarwal P, Cirelli D, Gu L, Surowy T, Mozier NM. Characterization of FcgammaRIIIA effector cells used in in vitro ADCC bioassay: comparison of primary NK cells with engineered NK-92 and Jurkat T cells. J Immunol Methods (2017) 441:56-66. doi:10.1016/j.jim.2016.12.002

104. Jochems C, Hodge JW, Fantini M, Fujii R, Morillon YM II, Greiner JW, et al. An NK cell line (haNK) expressing high levels of granzyme and engineered to express the high affinity CD16 allele. Oncotarget (2016) 7(52):86359-73. doi:10.18632/oncotarget.13411

105. Samara P, Skopeliti M, Tsiatas ML, Georgaki S, Gouloumis C, Voelter W, et al. A cytokine cocktail augments the efficacy of adoptive NK-92 cell therapy against mouse xenografts of human cancer. Anticancer Res (2016) 36(7):3373-82.

106. Alkins R, Burgess A, Kerbel R, Wels WS, Hynynen K. Early treatment of HER2-amplified brain tumors with targeted NK-92 cells and focused ultrasound improves survival. Neuro Oncol (2016) 18(7):974-81. doi:10.1093/ neuonc/nov318

107. Clémenceau B, Valsesia-Wittmann S, Jallas AC, Vivien R, Rousseau R, Marabelle A, et al. In vitro and in vivo comparison of lymphocytes transduced with a human $\mathrm{CD} 16$ or with a chimeric antigen receptor reveals potential off-target interactions due to the IgG2 CH2-CH3 CAR-spacer. J Immunol Res (2015) 2015:482089. doi:10.1155/2015/482089

108. Han J, Chu J, Keung Chan W, Zhang J, Wang Y, Cohen JB, et al. CARengineered NK cells targeting wild-type EGFR and EGFRvIII enhance killing of glioblastoma and patient-derived glioblastoma stem cells. Sci Rep (2015) 5:11483. doi:10.1038/srep11483

109. Schönfeld K, Sahm C, Zhang C, Naundorf S, Brendel C, Odendahl M, et al. Selective inhibition of tumor growth by clonal NK cells expressing an ErbB2/ HER2-specific chimeric antigen receptor. Mol Ther (2015) 23(2):330-8. doi:10.1038/mt.2014.219

110. Boissel L, Betancur-Boissel M, Lu W, Krause DS, Van Etten RA, Wels WS, et al. Retargeting NK-92 cells by means of CD19- and CD20-specific chimeric antigen receptors compares favorably with antibody-dependent cellular cytotoxicity. Oncoimmunology (2013) 2(10):e26527. doi:10.4161/onci. 26527

111. Chu J, Deng Y, Benson DM, He S, Hughes T, Zhang J, et al. CS1-specific chimeric antigen receptor (CAR)-engineered natural killer cells enhance in vitro and in vivo antitumor activity against human multiple myeloma. Leukemia (2014) 28(4):917-27. doi:10.1038/leu.2013.279

112. Li J, Liu H, Li L, Wu H, Wang C, Yan Z, et al. The combination of an oxygen-dependent degradation domain-regulated adenovirus expressing the chemokine RANTES/CCL5 and NK-92 cells exerts enhanced antitumor activity in hepatocellular carcinoma. Oncol Rep (2013) 29(3):895-902. doi:10.3892/or.2012.2217

113. Boissel L, Betancur M, Lu W, Wels WS, Marino T, Van Etten RA, et al. Comparison of mRNA and lentiviral based transfection of natural killer cells with chimeric antigen receptors recognizing lymphoid antigens. Leuk Lymphoma (2012) 53(5):958-65. doi:10.3109/10428194.2011.634048

114. Esser R, Müller T, Stefes D, Kloess S, Seidel D, Gillies SD, et al. NK cells engineered to express a GD2-specific antigen receptor display built-in ADCC-like activity against tumour cells of neuroectodermal origin. J Cell Mol Med (2012) 16(3):569-81. doi:10.1111/j.1582-4934.2011.01343.x

115. Boissel L, Betancur M, Wels WS, Tuncer H, Klingemann H. Transfection with mRNA for CD19 specific chimeric antigen receptor restores NK cell mediated killing of CLL cells. Leuk Res (2009) 33(9):1255-9. doi:10.1016/j. leukres.2008.11.024

116. MacLeod RA, Nagel S, Kaufmann M, Greulich-Bode K, Drexler HG. Multicolor-FISH analysis of a natural killer cell line (NK-92). Leuk Res (2002) 26(11):1027-33. doi:10.1016/S0145-2126(02)00055-3

117. Rosenberg SA, Dudley ME. Adoptive cell therapy for the treatment of patients with metastatic melanoma. Curr Opin Immunol (2009) 21(2):233-40. doi:10.1016/j.coi.2009.03.002

118. Besser MJ, Shapira-Frommer R, Treves AJ, Zippel D, Itzhaki O, Hershkovitz L, et al. Clinical responses in a phase II study using adoptive transfer of short-term cultured tumor infiltration lymphocytes in metastatic melanoma patients. Clin Cancer Res (2010) 16(9):2646-55. doi:10.1158/10780432.CCR-10-0041

119. Yee C, Thompson JA, Byrd D, Riddell SR, Roche P, Celis E, et al. Adoptive $\mathrm{T}$ cell therapy using antigen-specific $\mathrm{CD} 8+\mathrm{T}$ cell clones for the treatment of patients with metastatic melanoma: in vivo persistence, migration, and antitumor effect of transferred T cells. Proc Natl Acad Sci U S A (2002) 99(25):16168-73. doi:10.1073/pnas.242600099

120. Chen Y, You F, Jiang L, Li J, Zhu X, Bao Y, et al. Gene-modified NK-92MI cells expressing a chimeric CD16-BB-zeta or CD64-BB-zeta receptor exhibit enhanced cancer-killing ability in combination with therapeutic antibody. Oncotarget (2017) 8(23):37128-39. doi:10.18632/oncotarget.16201

121. Tanaka H, Kai S, Yamaguchi M, Misawa M, Fujimori Y, Yamamoto M, et al. Analysis of natural killer (NK) cell activity and adhesion molecules on NK cells from umbilical cord blood. Eur J Haematol (2003) 71(1):29-38. doi:10.1034/j.1600-0609.2003.00081.x

122. Dalle JH, Menezes J, Wagner E, Blagdon M, Champagne J, Champagne MA, et al. Characterization of cord blood natural killer cells: implications for transplantation and neonatal infections. Pediatr Res (2005) 57(5 Pt 1):649-55. doi:10.1203/01.PDR.0000156501.55431.20

123. Wang Y, Xu H, Zheng X, Wei H, Sun R, Tian Z. High expression of NKG2A/ CD94 and low expression of granzyme B are associated with reduced cord blood NK cell activity. Cell Mol Immunol (2007) 4(5):377-82.

124. Luevano M, Daryouzeh M, Alnabhan R, Querol S, Khakoo S, Madrigal A, et al. The unique profile of cord blood natural killer cells balances incomplete maturation and effective killing function upon activation. Hum Immunol (2012) 73(3):248-57. doi:10.1016/j.humimm.2011.12.015

125. Björkström NK, Riese P, Heuts F, Andersson S, Fauriat C, Ivarsson MA, et al. Expression patterns of NKG2A, KIR, and CD57 define a process of CD56dim NK-cell differentiation uncoupled from NK-cell education. Blood (2010) 116(19):3853-64. doi:10.1182/blood-2010-04-281675

126. Abo T, Miller CA, Balch CM. Characterization of human granular lymphocyte subpopulations expressing HNK-1 (Leu-7) and Leu-11 antigens in the blood and lymphoid tissues from fetuses, neonates and adults. Eur I Immunol (1984) 14(7):616-23. doi:10.1002/eji.1830140707

127. Bradstock KF, Luxford C, Grimsley PG. Functional and phenotypic assessment of neonatal human leucocytes expressing natural killer cell-associated antigens. Immunol Cell Biol (1993) 71(Pt 6):535-42. doi:10.1038/icb.1993.59

128. Shah N, Martin-Antonio B, Yang H, Ku S, Lee DA, Cooper LJ, et al. Antigen presenting cell-mediated expansion of human umbilical cord blood yields log-scale expansion of natural killer cells with anti-myeloma activity. PLoS One (2013) 8(10):e76781. doi:10.1371/journal.pone.0076781

129. Gill S, Vasey AE, De Souza A, Baker J, Smith AT, Kohrt HE, et al. Rapid development of exhaustion and down-regulation of eomesodermin limit the antitumor activity of adoptively transferred murine natural killer cells. Blood (2012) 119(24):5758-68. doi:10.1182/blood-2012-03-415364

130. Intlekofer AM, Takemoto N, Wherry EJ, Longworth SA, Northrup JT, Palanivel VR, et al. Effector and memory CD8+ T cell fate coupled by T-bet and eomesodermin. Nat Immunol (2005) 6(12):1236-44. doi:10.1038/ni1268

131. Sommermeyer D, Hill T, Shamah SM, Salter AI, Chen Y, Mohler KM, et al. Fully human CD19-specific chimeric antigen receptors for T-cell therapy. Leukemia (2017) 31(10):2191-9. doi:10.1038/leu.2017.57

132. Song DG, Ye Q, Poussin M, Liu L, Figini M, Powell DJ Jr. A fully human chimeric antigen receptor with potent activity against cancer cells but reduced risk for off-tumor toxicity. Oncotarget (2015) 6(25):21533-46. doi:10.18632/ oncotarget.4071

133. Sun M, Shi H, Liu C, Liu J, Liu X, Sun Y. Construction and evaluation of a novel humanized HER2-specific chimeric receptor. Breast Cancer Res (2014) 16(3):R61. doi:10.1186/bcr3674

134. Alonso-Camino V, Sánchez-Martín D, Compte M, Nuñez-Prado N, Diaz RM, Vile R, et al. CARbodies: human antibodies against cell surface tumor antigens selected from repertoires displayed on $\mathrm{T}$ cell chimeric antigen receptors. Mol Ther Nucleic Acids (2013) 2:e93. doi:10.1038/mtna.2013.19

135. Lanitis E, Poussin M, Hagemann IS, Coukos G, Sandaltzopoulos R, Scholler N, et al. Redirected antitumor activity of primary human lymphocytes transduced with a fully human anti-mesothelin chimeric receptor. Mol Ther (2012) 20(3):633-43. doi:10.1038/mt.2011.256

136. Zhao Y, Wang QJ, Yang S, Kochenderfer JN, Zheng Z, Zhong X, et al. A herceptin-based chimeric antigen receptor with modified signaling domains leads to enhanced survival of transduced T lymphocytes and antitumor activity. J Immunol (2009) 183(9):5563-74. doi:10.4049/jimmunol.0900447

137. Call ME, Schnell JR, Xu C, Lutz RA, Chou JJ, Wucherpfennig KW. The structure of the zetazeta transmembrane dimer reveals features essential for its assembly with the T cell receptor. Cell (2006) 127(2):355-68. doi:10.1016/j. cell.2006.08.044 
138. Gosse JA, Wagenknecht-Wiesner A, Holowka D, Baird B. Transmembrane sequences are determinants of immunoreceptor signaling. J Immunol (2005) 175(4):2123-31. doi:10.4049/jimmunol.175.4.2123

139. Yamasaki S, Ishikawa E, Kohno M, Saito T. The quantity and duration of FcRgamma signals determine mast cell degranulation and survival. Blood (2004) 103(8):3093-101. doi:10.1182/blood-2003-08-2944

140. Hudecek M, Lupo-Stanghellini MT, Kosasih PL, Sommermeyer D, Jensen MC, Rader C, et al. Receptor affinity and extracellular domain modifications affect tumor recognition by ROR1-specific chimeric antigen receptor T cells. Clin Cancer Res (2013) 19(12):3153-64. doi:10.1158/10780432.CCR-13-0330

141. Hombach A, Heuser C, Gerken M, Fischer B, Lewalter K, Diehl V, et al. T cell activation by recombinant FcepsilonRI gamma-chain immune receptors: an extracellular spacer domain impairs antigen-dependent $\mathrm{T}$ cell activation but not antigen recognition. Gene Ther (2000) 7(12):1067-75. doi:10.1038/ sj.gt.3301195

142. Dotti G, Gottschalk S, Savoldo B, Brenner MK. Design and development of therapies using chimeric antigen receptor-expressing T cells. Immunol Rev (2014) 257(1):107-26. doi:10.1111/imr.12131

143. Finney HM, Akbar AN, Lawson AD. Activation of resting human primary T cells with chimeric receptors: costimulation from CD28, inducible costimulator, CD134, and CD137 in series with signals from the TCR zeta chain. J Immunol (2004) 172(1):104-13. doi:10.4049/jimmunol.172.1.104

144. Finney HM, Lawson AD, Bebbington CR, Weir AN. Chimeric receptors providing both primary and costimulatory signaling in $\mathrm{T}$ cells from a single gene product. J Immunol (1998) 161(6):2791-7.

145. Moingeon P, Lucich JL, McConkey DJ, Letourneur F, Malissen B, Kochan J, et al. CD3 zeta dependence of the CD2 pathway of activation in T lymphocytes and natural killer cells. Proc Natl Acad Sci U S A (1992) 89(4):1492-6. doi:10.1073/pnas.89.4.1492

146. Vivier E, Ackerly M, Rochet N, Anderson P. Structure and function of the CD16:zeta:gamma complex expressed on human natural-killer cells. Int J Cancer Suppl (1992) 7:11-4.

147. Chen X, Allan DS, Krzewski K, Ge B, Kopcow H, Strominger JL. CD28stimulated ERK2 phosphorylation is required for polarization of the microtubule organizing center and granules in YTS NK cells. Proc Natl Acad Sci U S A (2006) 103(27):10346-51. doi:10.1073/pnas.0604236103

148. Lang S, Vujanovic NL, Wollenberg B, Whiteside TL. Absence of B7.1-CD28/ CTLA-4-mediated co-stimulation in human NK cells. Eur JImmunol (1998) 28(3):780-6. doi:10.1002/(SICI)1521-4141(199803)28:03<780:: AID-IMMU780>3.0.CO;2-8

149. Campbell KS, Colonna M. DAP12: a key accessory protein for relaying signals by natural killer cell receptors. Int J Biochem Cell Biol (1999) 31(6):631-6. doi:10.1016/S1357-2725(99)00022-9

150. Töpfer K, Cartellieri M, Michen S, Wiedemuth R, Müller N, Lindemann D, et al. DAP12-based activating chimeric antigen receptor for NK cell tumor immunotherapy. J Immunol (2015) 194(7):3201-12. doi:10.4049/jimmunol.1400330

151. Savoldo B, Ramos CA, Liu E, Mims MP, Keating MJ, Carrum G, et al. CD28 costimulation improves expansion and persistence of chimeric antigen receptor-modified T cells in lymphoma patients. J Clin Invest (2011) 121(5):1822-6. doi:10.1172/JCI46110

152. Tumaini B, Lee DW, Lin T, Castiello L, Stroncek DF, Mackall C, et al. Simplified process for the production of anti-CD19-CAR-engineered T cells. Cytotherapy (2013) 15(11):1406-15. doi:10.1016/j.jcyt.2013.06.003

153. Miller DG, Adam MA, Miller AD. Gene transfer by retrovirus vectors occurs only in cells that are actively replicating at the time of infection. Mol Cell Biol (1990) 10(8):4239-42. doi:10.1128/MCB.10.8.4239

154. van Til NP, Wagemaker G. Lentiviral gene transduction of mouse and human hematopoietic stem cells. Methods Mol Biol (2014) 1185:311-9. doi:10.1007/978-1-4939-1133-2_21

155. Lin P, Lin Y, Lennon DP, Correa D, Schluchter M, Caplan AI. Efficient lentiviral transduction of human mesenchymal stem cells that preserves proliferation and differentiation capabilities. Stem Cells Transl Med (2012) 1(12):886-97. doi:10.5966/sctm.2012-0086

156. Ye Z, Yu X, Cheng L. Lentiviral gene transduction of mouse and human stem cells.MethodsMolBiol(2008)430:243-53.doi:10.1007/978-1-59745-182-6_17

157. De Meyer SF, Vanhoorelbeke K, Chuah MK, Pareyn I, Gillijns V, Hebbel RP, et al. Phenotypic correction of von Willebrand disease type 3 blood-derived endothelial cells with lentiviral vectors expressing von Willebrand factor. Blood (2006) 107(12):4728-36. doi:10.1182/blood-2005-09-3605

158. Sadelain M. Insertional oncogenesis in gene therapy: how much of a risk? Gene Ther (2004) 11(7):569-73. doi:10.1038/sj.gt.3302243

159. Hacein-Bey-Abina S, Von Kalle C, Schmidt M, McCormack MP, Wulffraat N, Leboulch P, et al. LMO2-associated clonal T cell proliferation in two patients after gene therapy for SCID-X1. Science (2003) 302(5644):415-9. doi:10.1126/science. 1088547

160. Hacein-Bey-Abina S, von Kalle C, Schmidt M, Le Deist F, Wulffraat N, McIntyre E, et al. A serious adverse event after successful gene therapy for X-linked severe combined immunodeficiency. N Engl J Med (2003) 348(3):255-6. doi:10.1056/NEJM200301163480314

161. Aiuti A, Slavin S, Aker M, Ficara F, Deola S, Mortellaro A, et al. Correction of ADA-SCID by stem cell gene therapy combined with nonmyeloablative conditioning. Science (2002) 296(5577):2410-3. doi:10.1126/science.1070104

162. Brudno JN, Somerville RP, Shi V, Rose JJ, Halverson DC, Fowler DH, et al. Allogeneic $\mathrm{T}$ cells that express an anti-CD19 chimeric antigen receptor induce remissions of B-cell malignancies that progress after allogeneic hematopoietic stem-cell transplantation without causing graft-versus-host disease. J Clin Oncol (2016) 34(10):1112-21. doi:10.1200/JCO.2015.64.5929

163. Kebriaei P, Singh H, Huls MH, Figliola MJ, Bassett R, Olivares S, et al. Phase I trials using sleeping beauty to generate CD19-specific CAR T cells. J Clin Invest (2016) 126(9):3363-76. doi:10.1172/JCI86721

164. Johnson LA, June CH. Driving gene-engineered T cell immunotherapy of cancer. Cell Res (2017) 27(1):38-58. doi:10.1038/cr.2016.154

165. Sutlu T, Nystrom S, Gilljam M, Stellan B, Applequist SE, Alici E. Inhibition of intracellular antiviral defense mechanisms augments lentiviral transduction of human natural killer cells: implications for gene therapy. Hum Gene Ther (2012) 23(10):1090-100. doi:10.1089/hum.2012.080

166. Li L, Liu LN, Feller S, Allen C, Shivakumar R, Fratantoni J, et al. Expression of chimeric antigen receptors in natural killer cells with a regulatory-compliant non-viral method. Cancer Gene Ther (2010) 17(3):147-54. doi:10.1038/ cgt. 2009.61

167. Shimasaki N, Fujisaki H, Cho D, Masselli M, Lockey T, Eldridge P, et al. A clinically adaptable method to enhance the cytotoxicity of natural killer cells against B-cell malignancies. Cytotherapy (2012) 14(7):830-40. doi:10.3109/ 14653249.2012.671519

168. Anurathapan U, Chan RC, Hindi HF, Mucharla R, Bajgain P, Hayes BC, et al. Kinetics of tumor destruction by chimeric antigen receptor-modified $\mathrm{T}$ cells. Mol Ther (2014) 22(3):623-33. doi:10.1038/mt.2013.262

169. Imai C, Iwamoto S, Campana D. Genetic modification of primary natural killer cells overcomes inhibitory signals and induces specific killing of leukemic cells. Blood (2005) 106(1):376-83. doi:10.1182/blood-2004-12-4797

170. Chang YH, Connolly J, Shimasaki N, Mimura K, Kono K, Campana D. A chimeric receptor with NKG2D specificity enhances natural killer cell activation and killing of tumor cells. Cancer Res (2013) 73(6):1777-86. doi:10.1158/0008-5472.CAN-12-3558

171. Tassev DV, Cheng M, Cheung NK. Retargeting NK92 cells using an HLAA2-restricted, EBNA3C-specific chimeric antigen receptor. Cancer Gene Ther (2012) 19(2):84-100. doi:10.1038/cgt.2011.66

172. Locatelli F, Moretta F, Brescia L, Merli P. Natural killer cells in the treatment of high-risk leukemia. Semin Immunol (2014) 26(2):173-9. doi:10.1016/j. smim.2014.02.004

173. Yoon SR, Lee YS, Yang SH, Ahn KH, Lee JH, Lee JH, et al. Generation of donor natural killer cells from CD34(+) progenitor cells and subsequent infusion after HLA-mismatched allogeneic hematopoietic cell transplantation: a feasibility study. Bone Marrow Transplant (2010) 45(6):1038-46. doi:10.1038/bmt.2009.304

174. Rezvani K, Rouce RH. The application of natural killer cell immunotherapy for the treatment of cancer. Front Immunol (2015) 6:578. doi:10.3389/ fimmu.2015.00578

175. Asai O, Longo DL, Tian ZG, Hornung RL, Taub DD, Ruscetti FW, et al. Suppression of graft-versus-host disease and amplification of graft-versus-tumor effects by activated natural killer cells after allogeneic bone marrow transplantation. J Clin Invest (1998) 101(9):1835-42. doi:10.1172/JCI1268

176. Shlomchik WD, Couzens MS, Tang CB, McNiff J, Robert ME, Liu J, et al. Prevention of graft versus host disease by inactivation of host antigen-presenting cells. Science (1999) 285(5426):412-5. doi:10.1126/science.285. 5426.412 
177. Fujiwara S, Akiyama M, Yamakido M, Seyama T, Kobuke K, Hakoda M, et al. Cryopreservation of human lymphocytes for assessment of lymphocyte subsets and natural killer cytotoxicity. J Immunol Methods (1986) 90(2):265-73. doi:10.1016/0022-1759(86)90084-0

178. Dominguez E, Lowdell MW, Perez-Cruz I, Madrigal A, Cohen SB. Natural killer cell function is altered by freezing in DMSO. Biochem Soc Trans (1997) 25(2):175S. doi:10.1042/bst025175s

179. Voshol H, Dullens HF, Den Otter W, Vliegenthart JF. Human natural killer cells: a convenient purification procedure and the influence of cryopreservation on cytotoxic activity. J Immunol Methods (1993) 165(1):21-30. doi:10.1016/0022-1759(93)90102-D

180. Domogala A, Madrigal JA, Saudemont A. Cryopreservation has no effect on function of natural killer cells differentiated in vitro from umbilical cord blood CD34(+) cells. Cytotherapy (2016) 18(6):754-9. doi:10.1016/j. jcyt.2016.02.008

181. Koehl U, Brehm C, Huenecke S, Zimmermann SY, Kloess S, Bremm M, et al. Clinical grade purification and expansion of NK cell products for an optimized manufacturing protocol. Front Oncol (2013) 3:118. doi:10.3389/ fonc. 2013.00118

182. Lapteva N, Durett AG, Sun J, Rollins LA, Huye LL, Fang J, et al. Large-scale ex vivo expansion and characterization of natural killer cells for clinical applications. Cytotherapy (2012) 14(9):1131-43. doi:10.3109/14653249.201 2.700767

183. Fujisaki H, Kakuda H, Shimasaki N, Imai C, Ma J, Lockey T, et al. Expansion of highly cytotoxic human natural killer cells for cancer cell therapy. Cancer Res (2009) 69(9):4010-7. doi:10.1158/0008-5472.CAN-08-3712

184. Davis ZB, Felices M, Verneris MR, Miller JS. Natural killer cell adoptive transfer therapy: exploiting the first line of defense against cancer. Cancer J (2015) 21(6):486-91. doi:10.1097/PPO.0000000000000156

185. Becknell B, Caligiuri MA. Interleukin-2, interleukin-15, and their roles in human natural killer cells. Adv Immunol (2005) 86:209-39. doi:10.1016/ S0065-2776(04)86006-1

186. Antony GK, Dudek AZ. Interleukin 2 in cancer therapy. Curr Med Chem (2010) 17(29):3297-302. doi:10.2174/092986710793176410

187. Pedroza-Pacheco I, Madrigal A, Saudemont A. Interaction between natural killer cells and regulatory T cells: perspectives for immunotherapy. Cell $\mathrm{Mol}$ Immunol (2013) 10(3):222-9. doi:10.1038/cmi.2013.2

188. Waldmann TA, Lugli E, Roederer M, Perera LP, Smedley JV, Macallister RP, et al. Safety (toxicity), pharmacokinetics, immunogenicity, and impact on elements of the normal immune system of recombinant human IL-15 in rhesus macaques. Blood (2011) 117(18):4787-95. doi:10.1182/ blood-2010-10-311456

189. Conlon KC, Lugli E, Welles HC, Rosenberg SA, Fojo AT, Morris JC, et al. Redistribution, hyperproliferation, activation of natural killer cells and CD8 $\mathrm{T}$ cells, and cytokine production during first-in-human clinical trial of recombinant human interleukin-15 in patients with cancer. J Clin Oncol (2015) 33(1):74-82. doi:10.1200/JCO.2014.57.3329

190. Tam YK, Maki G, Miyagawa B, Hennemann B, Tonn T, Klingemann HG. Characterization of genetically altered, interleukin 2-independent natural killer cell lines suitable for adoptive cellular immunotherapy. Hum Gene Ther (1999) 10(8):1359-73. doi:10.1089/10430349950018030

191. Nagashima S, Mailliard R, Kashii Y, Reichert TE, Herberman RB, Robbins P, et al. Stable transduction of the interleukin-2 gene into human natural killer cell lines and their phenotypic and functional characterization in vitro and in vivo. Blood (1998) 91(10):3850-61.

192. Konstantinidis KV, Alici E, Aints A, Christensson B, Ljunggren HG, Dilber MS. Targeting IL-2 to the endoplasmic reticulum confines autocrine growth stimulation to NK-92 cells. Exp Hematol (2005) 33(2):159-64. doi:10.1016/j. exphem.2004.11.003

193. Liu E, Tong Y, Dotti G, Savoldo B, Muftuoglu M, Kondo K, et al. Cord blood derived natural killer cells engineered with a chimeric antigen receptor targeting CD19 and expressing IL-15 have long term persistence and exert potent anti-leukemia activity. Blood (2015) 126:3091.

194. Imamura M, Shook D, Kamiya T, Shimasaki N, Chai SM, Coustan-Smith E, et al. Autonomous growth and increased cytotoxicity of natural killer cells expressing membrane-bound interleukin-15. Blood (2014) 124(7):1081-8. doi:10.1182/blood-2014-02-556837

195. Sahm C, Schonfeld K, Wels WS. Expression of IL-15 in NK cells results in rapid enrichment and selective cytotoxicity of gene-modified effectors that carry a tumor-specific antigen receptor. Cancer Immunol Immunother (2012) 61(9):1451-61. doi:10.1007/s00262-012-1212-x

196. Hay KA, Hanafi LA, Li D, Gust J, Liles WC, Wurfel MM, et al. Kinetics and biomarkers of severe cytokine release syndrome after CD19 chimeric antigen receptor-modified T cell therapy. Blood (2017) 130(21):2295-306 doi:10.1182/blood-2017-06-793141

197. Fitzgerald JC, Weiss SL, Maude SL, Barrett DM, Lacey SF, Melenhorst JJ, et al. Cytokine release syndrome after chimeric antigen receptor $\mathrm{T}$ cell therapy for acute lymphoblastic leukemia. Crit Care Med (2017) 45(2):e124-31. doi:10.1097/CCM.0000000000002053

198. Greco R, Oliveira G, Stanghellini MT, Vago L, Bondanza A, Peccatori J, et al. Improving the safety of cell therapy with the TK-suicide gene. Front Pharmacol (2015) 6:95. doi:10.3389/fphar.2015.00095

199. Fillat C, Carrio M, Cascante A, Sangro B. Suicide gene therapy mediated by the herpes simplex virus thymidine kinase gene/ganciclovir system: fifteen years of application. Curr Gene Ther (2003) 3(1):13-26. doi: $10.2174 / 1566523033347426$

200. Ciceri F, Bonini C, Stanghellini MT, Bondanza A, Traversari C, Salomoni M, et al. Infusion of suicide-gene-engineered donor lymphocytes after family haploidentical haemopoietic stem-cell transplantation for leukaemia (the TK007 trial): a non-randomised phase I-II study. Lancet Oncol (2009) 10(5):489-500. doi:10.1016/S1470-2045(09)70074-9

201. Tiberghien P, Ferrand C, Lioure B, Milpied N, Angonin R, Deconinck E, et al. Administration of herpes simplex-thymidine kinase-expressing donor T cells with a T-cell-depleted allogeneic marrow graft. Blood (2001) 97(1):63-72. doi:10.1182/blood.V97.1.63

202. Bonini C, Ferrari G, Verzeletti S, Servida P, Zappone E, Ruggieri L, et al. HSV-TK gene transfer into donor lymphocytes for control of allogeneic graft-versus-leukemia. Science (1997) 276(5319):1719-24. doi:10.1126/ science.276.5319.1719

203. Di Stasi A, Tey SK, Dotti G, Fujita Y, Kennedy-Nasser A, Martinez C, et al. Inducible apoptosis as a safety switch for adoptive cell therapy. $N \mathrm{Engl} \mathrm{J} \mathrm{Med}$ (2011) 365(18):1673-83. doi:10.1056/NEJMoa1106152

204. Budde LE, Berger C, Lin Y, Wang J, Lin X, Frayo SE, et al. Combining a CD20 chimeric antigen receptor and an inducible caspase 9 suicide switch to improve the efficacy and safety of T cell adoptive immunotherapy for lymphoma. PLoS One (2013) 8(12):e82742. doi:10.1371/journal.pone.0082742

205. Hoyos V, Savoldo B, Quintarelli C, Mahendravada A, Zhang M, Vera J, et al. Engineering CD19-specific T lymphocytes with interleukin-15 and a suicide gene to enhance their anti-lymphoma/leukemia effects and safety. Leukemia (2010) 24(6):1160-70. doi:10.1038/leu.2010.75

206. Straathof KC, Pulè MA, Yotnda P, Dotti G, Vanin EF, Brenner MK, et al. An inducible caspase 9 safety switch for T-cell therapy. Blood (2005) 105(11):4247-54. doi:10.1182/blood-2004-11-4564

207. Wang X, Chang WC, Wong CW, Colcher D, Sherman M, Ostberg JR, et al. A transgene-encoded cell surface polypeptide for selection, in vivo tracking, and ablation of engineered cells. Blood (2011) 118(5):1255-63. doi:10.1182/ blood-2011-02-337360

208. Busch DH. Choice of better T-cells for adoptive immunotherapy. Blood (2015) 126:SCI-22.

209. Chu Y, Hochberg J, Yahr A, Ayello J, van de Ven C, Barth M, et al. Targeting CD20+ aggressive B-cell non-Hodgkin lymphoma by anti-CD20 CAR mRNA-Modified expanded natural killer cells in vitro and in NSG mice. CancerImmunol Res (2015) 3(4):333-44. doi:10.1158/2326-6066.CIR-14-0114

210. Müller T, Uherek C, Maki G, Chow KU, Schimpf A, Klingemann HG, et al. Expression of a CD20-specific chimeric antigen receptor enhances cytotoxic activity of NK cells and overcomes NK-resistance of lymphoma and leukemia cells. Cancer Immunol Immunother (2008) 57(3):411-23. doi:10.1007/ s00262-007-0383-3

211. Jiang $\mathrm{H}$, Zhang $\mathrm{W}$, Shang $\mathrm{P}$, Zhang $\mathrm{H}, \mathrm{Fu}$ W, Ye F, et al. Transfection of chimeric anti-CD138 gene enhances natural killer cell activation and killing of multiple myeloma cells. Mol Oncol (2014) 8(2):297-310. doi:10.1016/j. molonc.2013.12.001

212. Chen KH, Wada M, Firor AE, Pinz KG, Jares A, Liu H, et al. Novel anti-CD3 chimeric antigen receptor targeting of aggressive $\mathrm{T}$ cell malignancies. Oncotarget (2016) 7(35):56219-32. doi:10.18632/oncotarget.11019

213. Sinha C, Seth A, Kahali B, Cunningham L. Development and evaluation of NK-CD123 CAR against high risk acute myeloid leukemia. Biol Blood Marrow Transplant (2017) 23(3):S253. doi:10.1016/j.bbmt.2016.12.423 
214. Kruschinski A, Moosmann A, Poschke I, Norell H, Chmielewski M, Seliger B, et al. Engineering antigen-specific primary human NK cells against HER-2 positive carcinomas. Proc Natl Acad Sci US A (2008) 105(45):17481-6. doi:10.1073/pnas.0804788105

215. Liu H, Yang B, Sun T, Lin L, Hu Y, Deng M, et al. Specific growth inhibition of ErbB2expressing human breast cancer cells by genetically modified NK92 cells. Oncol Rep (2015) 33(1):95-102.

216. Uherek C, Tonn T, Uherek B, Becker S, Schnierle B, Klingemann HG, et al. Retargeting of natural killer-cell cytolytic activity to ErbB2-expressing cancer cells results in efficient and selective tumor cell destruction. Blood (2002) 100(4):1265-73.

217. Zhao Q, Ahmed M, Tassev DV, Hasan A, Kuo TY, Guo HF, et al. Affinity maturation of T-cell receptor-like antibodies for Wilms tumor 1 peptide greatly enhances therapeutic potential. Leukemia (2015) 29(11):2238-47. doi:10.1038/leu.2015.125

218. Park H, Awasthi A, Ayello J, Chu Y, Riddell S, Rosenblum J, et al. ROR1specific chimeric antigen receptor (CAR) NK cell immunotherapy for high risk neuroblastomas and sarcomas. Biol Blood Marrow Transplant (2017) 23(3 Suppl):S136-7. doi:10.1016/j.bbmt.2017.01.056

219. Tagaya Y, Bamford RN, DeFilippis AP, Waldmann TA. IL-15: a pleiotropic cytokine with diverse receptor/signaling pathways whose expression is controlled at multiple levels. Immunity (1996) 4(4):329-36. doi:10.1016/ S1074-7613(00)80246-0

Conflict of Interest Statement: The authors declare that the research was conducted in the absence of any commercial or financial relationships that could be construed as a potential conflict of interest.

Copyright $(2018$ Mehta and Rezvani. This is an open-access article distributed under the terms of the Creative Commons Attribution License (CC BY). The use, distribution or reproduction in other forums is permitted, provided the original author $(s)$ and the copyright owner are credited and that the original publication in this journal is cited, in accordance with accepted academic practice. No use, distribution or reproduction is permitted which does not comply with these terms. 